\title{
Partial Budgeting of the Application of Teat-dipping to Control Mastitis in Small Farms
}

\author{
Etih Sudarnika', Dikky Indrawan ${ }^{2 *}$, Abdul Zahid', Nyayu Lathifah Tirdasari ${ }^{2}$, \\ Chaerul Basri', Mirnawati Sudarwanto' \\ ${ }^{1}$ Faculty of Veterinary Medicine, \\ IPB University, Bogor, Indonesia \\ ${ }^{2}$ School of Business, \\ IPB University, Bogor, Indonesia \\ ${ }^{*}$ Corresponding author: rdikky@apps.ipb.ac.id \\ Submitted 7 November 2019, Accepted 22 December 2019
}

\begin{abstract}
Subclinical mastitis has a higher prevalence than clinical mastitis in many small farmers in Bogor city, and it could reach more than 80 percent. However, the application of teat-dipping could help small farms to control subclinical mastitis prevalence. The objective of this study was to measure the cost of teat-dipping application as subclinical mastitis control in small dairy farms. The partial budget was employed based on the experimental data collected in small dairy farms in Bogor. A number of cows were the basis of simulation for the mean of milk value and the application cost. The findings show an incentive for farmers to apply teat dipping in their farms. The incentive of teat dipping application could be improved to prevent sub-clinical mastitis infection and increase milk production.
\end{abstract}

Keywords: teat dipping, dairy, mastitis, small farms, partial budgeting

\begin{abstract}
ABSTRAK
Para peternak kecil di Kota Bogor mengalami prevalensi mastitis subklinis yang lebih tinggi hingga mencapai lebih dari 80 persen dibandingkan dengan mastitis klinis. Namun prevalensi mastitis subklinis dapat dikontrol dengan penerapan teat-dipping yang dapat membantu peternak kecil. Tujuan dari penelitian ini adalah untuk mengukur biaya aplikasi teat-dipping untuk mengendalikan mastitis subklinis di peternakan sapi perah kecil. Pengukuran biaya tersebut menggunakan metode partial budget yang dihitung berdasarkan data eksperimen yang dikumpulkan di peternakan sapi perah kecil di Bogor. Nilai rata-rata susu dan biaya aplikasi dihitung untuk mensimulasikan pendapatan berdasarkan ukuran jumlah sapi di peternakan. Hasil penelitian ini menunjukkan bahwa terdapat insentif ekonomi bagi petani untuk menerapkan teat-dipping di peternakan mereka. Insentif ekonomi dari aplikasi teat-dipping dapat ditingkatkan untuk mencegah infeksi mastitis subklinis dan meningkatkan produksi susu.
\end{abstract}

Kata kunci: teat-dipping, susu, mastitis, peternakan kecil, partial budgeting 


\section{INTRODUCTION}

Mastitis is well known as an endemic disease that has a significant economic loss in the dairy industry, especially in small farms (Getaneh et al. 2017; Gussmann et al. 2019). Mastitis may influence cows to yield less milk and reduced quality or even inconsumable milk (Huijps et al. 2008). Mastitis consists of 2 categories: subclinical mastitis that measured by bulk tank somatic cell count and clinical mastitis that measured by the incidence rate of clinical mastitis. Subclinical mastitis can spread to other healthy cows, which can cause higher clinical and leads to culling (van den Borne et al. 2010; Huijps et al. 2010). In many small farmers in Bogor city, the incident of subclinical mastitis could reach more than 80 percent higher than clinical mastitis. Therefore, many small farmers in Bogor are facing economic losses.

Treatment during lactation is suggested to improve udder health and to control subclinical mastitis prevalence (Swinkels et al. 2005). One of the treatments that can be used for small farmers is the application of teat-dipping. An expert mentions that the application of teat-dipping could reduce the probability of subclinical mastitis and prevent the spread to other healthy cows (Gussmann et al. 2019; van den Borne et al. 2010). However, the application of teat-dipping will increase the costs of milk production from labor and medicine usage. This cost incurred will discourage small farmers to perform teat-dipping to control subclinical mastitis, especially when there are no significant benefits (Huijps et al. 2008). Therefore, the increasing cost should be calculated and described to ensure it can motivate farmers to perform teat-dipping.

A thorough assessment of the cost of performing teat-dipping at small farms under Bogor district circumstances has not been performed before. Therefore, the objective of this study was to measure the cost of teat-dipping application as subclinical mastitis control in small dairy farms at Bogor.

\section{MATERIAL AND METHODS}

The partial budget was employed to calculate the cost of teat-dipping treatment (Huijps et al. 2010; Swinkels et al. 2005). Partial budgeting is a wellknown tool to help farmers evaluate the financial effect of incremental production changes (Huijps et al. 2010). It measured activity that changed and its financial impact. The change under treatment was evaluated for its impact on farmers' income. Partial budgets were calculated based on the business changes effects in income, cost reduction, and cost increase (Huijps et al. 2010).

The input variable was based on the experimental data collected in three small dairy farms in Bogor related to literature and on Bogor prices and conditions in 2019. The three dairy farms were Edufarm, H Acep farm, and Achmad Taufik Farm. The experiment was performed and measured on 4 teats of 34 cows at these farms (Table 1 ).

The experiment and the partial budget model were developed as follows:

1. The experimental was differentiated between two types of cows: without treatment (control) and treatment.

2. The effect of control and treatment was measured and compared by bulk tank somatic cell count for 13 consecutive weeks.

3. The milk production was measured weekly for 13 consecutive weeks.

4. The mean cost for cows on each farm was calculated based on control and treatment. Then the cost was compared to examine the added cost and/or cost reduction.

5. Then the cost was calculated at the cow level for one-time lactation.

6. The revenue was calculated based on the milk production for each teat and associated with Bogor city milk price. Then the revenue compared to examine added revenue and/or revenue reduction.

7. The cost and the revenue were compared and associated with the bulk tank somatic cell count.

Table 1 Information on The Farm Experiment

\begin{tabular}{cccc}
\hline Information & Edufarm & H. Acep Farm & A. Taufiq Farm \\
\hline Control & & & \\
$\bullet$ Cows & 15 & 3 & \\
$\bullet$ Observation & 558 & 98 & \\
\hline Treatment & & & \\
$\bullet$ Cows & & 14 & 104 \\
\hline Observation & & 734 & \\
\hline
\end{tabular}


8. The mean of milk value and the application cost were simulated by the farm revenue based on a number of cows.

Lastly, we analyzed the revenue and cost difference in combination with revenue to compare the application of without and with teat-dipping. The analysis was used to evaluate the ability of the application as an incentive to motivate the farmers. We analyzed the net benefit by deducted the incremental revenue between the application of without and with teat-dipping with the incremental cost. Then, we calculated the ratio between the net benefit with the incremental cost. Then we checked whether the ratio is higher or lower than 1. If the ratio is higher than 1 , then the application of teat-dipping provides an incentive for farmers. On the other hand, If the ratio is lower than 1, then the application of teat-dipping does not provide an incentive for farmers.

\section{RESULTS}

The study found that the application of teatdipping by small farmers was not having impressive results in reducing subclinical mastitis (Table 2). On average, the health percentage was slightly better on the cows with teat-dipping treatment. The improvement was only 1.75 percent.
The study found that teat-dipping treatment had changed milk productivity (Table 2 ). The production was found to be increased for 2-3 liters per teat. The study also found that there were no differences in the somatic cell count between the cow with teatdipping treatment and the cow without treatment (control). The comparison shows that the cow with teat-dipping treatment had higher milk production than the cow without treatment (control). The teat 2 and 3 milk productions were higher under the teatdipping treatment.

The study found an added cost of the teatdipping application. Table 3 shows that the cow with teat-dipping treatment had a higher cost compare to the cow without treatment (control). The average production cost was found around $\mathrm{Rp}$ 70,000 higher for a cow with teat-dipping treatment. The difference came from the animal health cost and household labor cost.

In detail, Table 3 shows that the total cost of milk production without teat-dipping control per cow per month was Rp 1,365,370, and the total revenue was $\operatorname{Rp~1,367,008~per~cow~per~month.~Consequently,~}$ the profit from milk production without teatdipping was only Rp 1,638 per cow per month. Whereas, the total cost of milk production with teatdipping control per cow per month was Rp 1,423,162,

Table 2 Production Comparison Between Without Treatment and With Treatment

\begin{tabular}{lcc}
\hline \multicolumn{1}{c}{ Items } & Control & Treatment \\
\hline $\begin{array}{l}\text { Average production cost (Rp/ } \\
\text { cow/month) }\end{array}$ & $1,373,307$ & $1,449,698$ \\
\hline Number of Cows & 18 & 16 \\
\hline $\begin{array}{l}\text { Average Half-day Production (li- } \\
\text { ter/cow/month) }\end{array}$ & & \\
- Teat 1 & 4.2 & 5.6 \\
- Teat 2 & 5.1 & 7.1 \\
- Teat 3 & 4.1 & 7.5 \\
- Teat 4 & 3.5 & 5.3 \\
\hline \% subclinical & & \\
- Teat 1 & 74 & 65 \\
- Teat 2 & 62 & 65 \\
- Teat 3 & 61 & 57 \\
- Teat 4 & 66 & 69 \\
\hline \% health & & 35 \\
- Teat 1 & 26 & 35 \\
- Teat 2 & 38 & 43 \\
- Teat 3 & 39 & 31 \\
\hline
\end{tabular}

Note: Teat number 1 referred to the right-front, teat number 2 referred to the right-back, teat number 3 referred to leftback, and teat number 4 referred to left-front. 
Table 3 Calculation of Cost and Benefit Between Control and Teat-Dipping Treatment Per Cow Per Month

\begin{tabular}{|c|c|c|}
\hline Items & Control (Rp) & Treatment (Rp) \\
\hline \multicolumn{3}{|l|}{ Direct Cost } \\
\hline Concentrate & 538,042 & 538,042 \\
\hline Tofu pulp & 166,125 & 166,125 \\
\hline Grass & 47,037 & 47,037 \\
\hline Non-household labor & 38,190 & 38,190 \\
\hline Mineral & 3,452 & 3,452 \\
\hline Vaseline & 6,883 & 6,883 \\
\hline Butter & 111 & 111 \\
\hline Animal Health & 54,136 & 62,136 \\
\hline Electricity & 1,237 & 1,237 \\
\hline Total Direct Cost & 855,213 & 863,213 \\
\hline \multicolumn{3}{|l|}{ Indirect Cost } \\
\hline Grass & 140,262 & 140,262 \\
\hline Household labor & 168,296 & 218,088 \\
\hline Rent a cage & 79,236 & 79,236 \\
\hline Livestock Shrinkage & 104,167 & 104,167 \\
\hline Depreciation of equipment & 18,196 & 18,196 \\
\hline Total Indirect Cost & 510,157 & 559,949 \\
\hline Total Cost & $1,365,370$ & $1,423,162$ \\
\hline \multicolumn{3}{|l|}{ Revenue } \\
\hline Production Sales & $1,367,008$ & $1,957 \cdot 950$ \\
\hline Total Revenue & $1,367,008$ & $1,957.950$ \\
\hline
\end{tabular}

and the total revenue was $\mathrm{Rp} 1,957,950$ per cow per month. Therefore, the profit gained from the teatdipping treatment was Rp 534,788 per cow per month. The higher benefit was found with teatdipping treatment since the milk production was found higher. Even the price was found stabile, and the total revenue was increased due to the increase in milk production.

Table 4 shows that the net benefit from teatdipping treatment was Rp533,150 per cows per month. Therefore, the application of the teatdipping treatment on small farms was 9,2. The ratio shows that incremental cost could increase incremental revenue to motivate small farmers.

\section{DISCUSSION}

The findings show that despite the subclinical mastitis in small farmers in Bogor city could not immediately be reduced by the application of teatdipping, there was an incentive for farmers to apply teat dipping in their farms. The number of subclinical mastitis was still high despite the application of teat dipping. We suspected that several problems might limit the efforts to reduce subclinical mastitis. First, the lack of farmers' knowledge and discipline in performing the application of teat-dipping (Huijps et al. 2008). Change of behavior was critically important in ensuring farmers' knowledge, attitude, and practice (Getaneh et al. 2017). Second, since the farmers could not change their habit immediately, there was a possibility of disease spreads between cows. Third, there was a possibility of disease spreads between farms. The disease spread between farms was possible due to the farms were located very close.

To increase the success rate, we believe that some improvements in teat-dipping applications are needed (Huijps et al. 2008). For instance, by changing the usage and dosage of medicine, and/or by changing the standard operating and procedures, and by improving the farmers' skills. Moreover, it may be helpful to improve the farm infrastructure such as floor bedding and farm sheds and cages. Therefore, the application of teat-dipping could be more effective. 
Table 4 Calculation of Benefit Ratio as an Incentive For Farmers Per Cow Per Month

\begin{tabular}{lccc}
\hline \multicolumn{1}{c}{ Items } & Control (Rp) & Treatment (Rp) & Incremental (Rp) \\
\hline Total Revenue (A) & $1,367,008$ & $1,957.950$ & 590.942 \\
Total Cost (B) & $1,365,370$ & $1,423,162$ & 57.792 \\
Net benefit (C) & & & 533,150 \\
Ratio (C/B) & & & 9.2 \\
\hline
\end{tabular}

In this study, we found that the cost and the revenue were increase due to the teat-dipping application for small farmers. The cost of the application of teat-dipping was found to increase the total farm cost. In this study, we could not find the reduced cost by this application of teat-dipping. The finding may be happened due to the limited success of the teat-dipping to reduce subclinical mastitis. The cost increased was countered by the revenue increased. By comparing the incremental increased between cost and revenue, we found that the application of teat-dipping gives the benefit that can be used as an incentive to motivate farmers (van den Borne et al. 2010; Huijps et al. 2010). However, despite the possibility of using the incremental revenue increased, it seems that the increase was not able to motivate farmers to applied the teat-dipping voluntarily.

In general, the incentive of teat dipping application should be improved to prevent sub-clinical mastitis infection. The successful rate to increase milk production by teat-dipping application was limited due to the application could not prevent subclinical mastitis infection. By improving the teat-dipping application will prevent subclinical mastitis and increase milk production. Then, we assume that the improvement may be resulting in a better incentive to motivate small farmers in implementing a teatdipping application.

\section{CONCLUSION}

The study found that the teat-dipping application as subclinical mastitis control in small dairy farms at Bogor increased the farm cost. Interestingly, the revenue received by their farmers was higher than its cost due to the impact of teat-dipping increased milk production. Consequently, the benefit ratio of the application of teat-dipping treatment confirmed an economic impact gives an incentive for the small farmers. However, the prevalence of subclinical mastitis could not be reduced drastically. The finding may be caused by farmers' habit, behavior and farm infrastructure. Therefore, the teat-dipping application should be improved by improving small farmers' knowledge and attitude alongside with their infrastructure to have a better incentive for farmers in implementing the application.

\section{ACKNOWLEDGEMENTS}

Ristekdikti Grant funded this study.

"All authors declare that there are no conflicts of interest".

\section{REFERENCES}

Getaneh AM, Mekonnen SA, HogeveenH. 2017. Stochastic bio-economic modeling of mastitis in Ethiopian dairy farms. Prev Vet Med. 138:94-103.

Gussmann M, Steeneveld W, Kirkeby C, Hogeveen H, Farre M, Halasa T. 2019. Economic and epidemiological impact of different intervention strategies for subclinical and clinical mastitis. Prev Vet Med. 166:78-85.

Huijps K, Lam TJ, Hogeveen H. 2008. Costs of mastitis: facts and perception. J Dairy Res. 75(1): 113120.

Huijps K, Hogeveen H, Lam TJ, Lansink AO. 2010. Costs and efficacy of management measures to improve udder health on Dutch dairy farms. J Dairy Sci. 93(1): 115-124.

Swinkels J, Hogeveen H, Zadoks R. 2005. A partial budget model to estimate economic benefits of lactational treatment of subclinical Staphylococcus aureus mastitis. J Dairy Sci. 88(12): 4273-4287.

van den Borne BH, Halasa T, van Schaik G, Hogeveen $\mathrm{H}$, Nielen M. 2010. Bioeconomic modeling of lactational antimicrobial treatment of new bovine subclinical intramammary infections caused by contagious pathogens. J Dairy Sci. 93(9): 40344044. 